\title{
Maintaining grass coverage increases methane uptake in Amazonian pasture soils
}

3 Leandro Fonseca de Souza ${ }^{1}$, Dasiel Obregon Alvarez ${ }^{1,2}$, Luiz A. Domeignoz-Horta ${ }^{3,4}$, Fabio 4 Vitorino Gomes ${ }^{1}$, Cassio de Souza Almeida ${ }^{1}$, Luis Fernando Merloti ${ }^{1}$, Lucas William Mendes ${ }^{1}$,

5 Fernando Dini Andreote ${ }^{5}$, Brendan J. M. Bohannan ${ }^{6}$, Jorge M. Rodrigues ${ }^{7}$, Klaus Nüsslein ${ }^{3}$, Siu Mui Tsai ${ }^{1}$

$8{ }^{1}$ Center for Nuclear Energy in Agriculture, University of Sao Paulo, Piracicaba, SP, Brazil

$9 \quad{ }^{2}$ Applied Soil Ecology Lab, School of Environmental Sciences, University of Guelph, Guelph,

10 ON, Canada

11 32Department of Microbiology, University of Massachusetts, Amherst, MA, USA

$12{ }^{4}$ Department of Evolutionary Biology and Environmental Studies, University of Zurich, Zurich,

13 Switzerland

$14{ }^{5}$ Luiz de Queiroz College of Agriculture, University of São Paulo, Piracicaba, SP, Brazil

$15{ }^{6}$ Institute of Ecology and Evolution, University of Oregon, Eugene, OR, USA

$16{ }^{7}$ Department of Land, Air and Water Resources, University of California Davis, CA, USA

18 Corresponding author: leandro_fonseca@alumni.usp.br

20 Running Title: Grass rhizosphere drives soil methane cycle 


\section{Abstract}

23 Cattle ranching is the largest driver of deforestation in the Brazilian Amazon. The rainforest-

24 to-pasture conversion affects the methane cycle in upland soils, changing it from sink to

25 source of atmospheric methane. However, it remains unknown if management practices could

26 reduce the impact of land-use on methane cycling. In this work, we evaluated how pasture

27 management can regulate the soil methane cycle either by maintaining continuous grass

28 coverage on pasture soils, or by liming the soil to amend acidity. Methane fluxes from forest

29 and pasture soils were evaluated in moisture-controlled greenhouse experiments with and

30 without grass cover (Urochloa brizantha cv. Marandu) or liming. In parallel, we assessed

31 changes in the soil microbial community structure of both bare pasture soil as well as

32 rhizosphere soil through high throughput sequencing of the 16S rRNA gene, and quantified

33 the methane cycling microbiota by their respective marker genes related to methane

34 generation (mcrA) or oxidation (pmoA). The experiments used soils from eastern and western

35 Amazonia, and concurrent field studies allowed us to confirm greenhouse data. The presence

36 of a grass cover not only increased methane uptake by up to $35 \%$ in pasture soils, but also

37 reduced the abundance of the methane-producing community. In the grass rhizosphere this

38 reduction was up to 10-fold. Methane-producing archaea belonged to the genera

39 Methanosarcina sp., Methanocella sp., Methanobacterium sp., and Rice Cluster I. Further, we

40 showed that liming compromised the capacity of forest and pasture soils to be a sink for

41 methane, and instead converted formerly methane-consuming forest soils to become

42 methane sources in only 40-80 days. Our results demonstrate that pasture management that

43 maintains grass coverage can mitigate soil methane emissions, if compared to a bare pasture

44 soil.

46 Keyword: climate change, soil methane cycling, environmental microbiology, soil 


\section{Introduction}

The establishment of pasture lands is the main cause of deforestation in the Amazon region (Dias et al., 2016; Margulis, 2003). This transformation of rainforest into pastures leads to the net increased emission of the powerful greenhouse gas methane, and turns a methane consuming forest soil into a methane producing pasture soil (Meyer et al., 2020; Fernandes et al., 2002; Steudler et al., 1996; Goreau; De Mello, 1988). The resulting greenhouse gas emissions account for half of Brazil's greenhouse gas production, and have already exceeded national emissions from fossil fuel by more than 20\% (Bustamante et al., 2012; Fearnside \& Imbrozio Barbosa, 1998). Livestock production is responsible for the emission of several greenhouse gases, and current studies work on minimizing this impact (Herrero et al. 2016, Fiqueiredo et al. 2017). Recently, methane emissions from soil have become a focus of investigations because they might be agriculturally manageable. The impact of land-use conversion on the annual balance of gas fluxes is noticeable considering pastures in western Amazonia can emit up to $270 \mathrm{mg} \mathrm{C}-\mathrm{CH}_{4} / \mathrm{m}^{2}$, while nearby forest soils can consume up to 470 mg C-CH $4 ~ m^{2}$ (Steudler et al., 1996).

Methane $\left(\mathrm{CH}_{4}\right)$ gas has an 86-fold greater potential to retain heat in the atmosphere compared to that of $\mathrm{CO}_{2}$, calculated over a 20-year period (IPCC, 2013). The global methane emissions are mainly driven by human activities such as livestock, irrigated agriculture, oil and gas production, and landfill decomposition (IPCC, 2013). Soil methane cycling is strongly dependent on the microbiota, since the biogenic source of this gas are methanogenic archaea. The biological consumption of methane is controlled by methanotrophs, mostly bacteria. In soil, the balance between methanotrophic bacteria and methanogenic archaea is related to environmental conditions (i.e., moisture, temperature, soil density, and $\mathrm{pH}$ ) and is sensitive to changes in agricultural management (Le Mer \& Roger, 2001; Liu et al., 2007; Tian et al., 2015).

Methanotrophic bacteria in the soil are Gram-negative, belonging to Gammaproteobacteria and Alphaproteobacteria, Verrucomicrobia, and candidates in the phylum NC10 (Hanson \& Hanson, 1996; Knief, 2015, Ettwig et al. 2010). The initial step of methane oxidation occurs through its conversion to methanol, which is mediated by the enzyme methane monooxygenase (MMO). Methanogenic archaea traditionally comprise members from eight orders within the phylum Euryarcheota: Methanopyrales, 
83 Methanobacteriales, Methanococcales, Methanomicrobiales, Methanocellales,

84 Methanosarcinales, Methanomassiliicoccales, and 'Candidatus Methanophagales' (Evans et 85 al. 2019), with additional candidates in the phylum Bathyarchaeota (Kallistova et al., 2017).

86 Methanogenesis is controlled by archaea and is the final step in an anaerobic pathway that 87 begins with the hydrolysis of organic polymers, fermentation of the resulting monomers and of 88 initial fermentation products, and ends up in the production of $\mathrm{CH}_{4}$ mostly from acetate, 89 hydrogen, and $\mathrm{CO}_{2}$. The final step in the methanogenesis pathway is facilitated through the 90 action of the enzyme methyl-coenzyme $M$ reductase, coded by the mcrA gene, which can be 91 used as a methanogen-specific marker for molecular studies (Serrano-Silva et al., 2014). The 92 ability to produce methane has recently been demonstrated in cyanobacteria and plants, 93 however, it is believed that this is a by-product from reactions of photosynthesis (Bižić et al., 94 2020; Keppler et al., 2006).

$95 \quad$ The relationship between changes in land-use and the response of the soil microbial 96 community is not well understood (Nazaries et al., 2013; Tate, 2015), but previous studies 97 have shown significant impacts on microbial diversity in the Amazon region (de Carvalho et 98 al., 2016; Mendes et al., 2015; Navarrete et al., 2015; Rodrigues et al., 2013; Jesus et al., 99 2009). In well-managed pastures in the Amazon region, the grass root system can redistribute 100 carbon to deeper layers, where it is less susceptible to decomposition (Fearnside \& Imbrozio 101 Barbosa, 1998). On the other hand, we can expect that degraded pastures with large bare 102 soil areas can facilitate the release of carbon from the system, with superficial grassroots, 103 higher loss of soil organic matter, and lower carbon stocks (Segnini et al. 2019). Proper 104 management of pasture may involve several practices, such as soil acidity correction and 105 continuous maintenance of grass cover to protect soil from erosion. These practices are 106 particularly important in the Amazon region given the environmental extremes of this area. 107 Altogether, the high soil acidity, high rainfall, and high temperatures combined with exposure 108 of the soil to equatorial solar radiation constitute factors that are associated with increasing 109 erosion and soil degradation (Demattê and Demattê, 1993). Soil degradation is the long-term 110 decline in the soil's productivity and its environment moderating capacity, with soil quality loss 111 and reduction in attributes related to specific functions of value to humans (Lal, 2001).

112 The effect of soil liming on methane fluxes is still poorly understood, and studies of 113 temperate forests show that liming can lead to both an increase and a decrease of methane 
114 consumption (Wang et al. 2021; Borken and Brumme, 1997; Butterbach-Bahl et al., 2002). In

115 wheat-focused agriculture liming has led to an increased consumption of methane in soil 116 (Hütsch et al., 1994). The increased methane consumption after liming was also observed in 117 Mediterranean semiarid soils under lupine, wheat, and triticale, a hybrid of wheat and rye 118 (Barton et al., 2013; García-Marco et al., 2016). However, for tropical soils little information is 119 available regarding what influence liming has on methane production and consumption. In an 120 assessment of greenhouse gas fluxes from soils under soybean cultivation in Brazil, the 121 acidity correction presented no effect on methane fluxes (Lammel et al., 2018). Likewise, in a 122 field experiment in Puerto Rico, soil consumption of atmospheric $\mathrm{CH}_{4}$ in an intentionally 123 acidified soil was about one-fourth of that at $\mathrm{pH} \mathrm{6,} \mathrm{and} \mathrm{was} \mathrm{not} \mathrm{restored} \mathrm{after} \mathrm{liming} \mathrm{(Mosier} \mathrm{et}$ 124 al., 1998).

125 There is a growing consensus that the key to understand major soil functions lies 126 where plants and soil meet, in the rhizosphere (Lau et al., 2011). The rhizosphere is a micro127 environment with differentiated soil conditions and steep overlapping gradients, in which $\mathrm{pH}$ 128 can be up to 2 units more acidic or more basic than the soil surrounding the rhizosphere. The 129 rhizosphere can present heterogeneous concentrations of oxygen and moisture and can be 130 enriched in root exudates like sugars and organic acids (Philippot et al., 2013). These factors 131 affect soil methane cycling not only by providing organic substrate for methanogenesis but 132 also by promoting the oxidation of methane in the rhizosphere. Despite its known role in 133 flooded rice soils (Frenzel et al., 1992), little is known about the impact of the rhizosphere on 134 methane cycling in upland soils since these soils are commonly considered to be a methane 135 sink, not a source (Philippot et al., 2009). Thus, improved understanding of how the 136 rhizosphere of land-intensive tropical pastures affects soil methane cycling can yield new 137 strategies to mitigate greenhouse gas emissions related to cattle ranching.

$138 \quad$ The intensive land use in agriculture and cattle ranching in Amazonia leads to soil and 139 pasture degradation ranging from $50 \%$ to $70 \%$ of total area (Dias-Filho, 2017). Within this 140 context this research aims to evaluate how the management of pastures can affect soil 141 methane cycling. We hypothesized that $\mathrm{CH}_{4}$ production is reduced by liming soils and by 142 continuous grass coverage due to the influence of the rhizosphere of Urochloa brizantha cv. 143 Marandu, a grass widely used in pastures in Brazil. To test this hypothesis, we measured 144 methane fluxes in soils from pasture field sites with and without grass cover, and compared 
145 the microbiota in bare pasture soil to that of the rhizosphere of grass covered soil. These 146 studies were complemented with greenhouse experiments where soil acidity was adjusted 147 and grass was planted, gas flux rates of the soil-air $\mathrm{CH}_{4}$-fluxes were measured, and shifts in 148 the soil microbial community between bare soil and the rhizosphere of Urochloa brizantha cv. 149 Marandu were determined.

\section{Materials and Methods}

\section{Sampling}

These studies were performed with soils from both western and eastern Amazonia. In the western region (hereafter "Ariquemes") sampling was carried out in April of 2017 at the region (hereafter "Tapajós"), the samples were taken at the National Forest of Tapajós and the immediately surrounding areas near Belterra, PA (307'53.8" S, 5457'24.2" W), in August of 2019. The sampled soils were used in two rounds of greenhouse experiments at the Center for Nuclear Energy in Agriculture, SP, Brazil (2242'27.7" S, 47³8'41.0" W). In addition to the soil sampling a field study was performed, but only in the Tapajós region (detailed below).

Western Amazonia has been studied for the impacts of conversion from forest to pasture, with extensive scientific literature characterizing ecosystem responses to conversion 164 (de Moraes et al., 1996; Herpin et al., 2002; Reiners et al., 1994) for representing a region with a high degree of exploitation. The Fazenda Nova Vida region has fragments of primary forest and pastures of different ages. The sampled pasture area was established in 1972, and

167 since then managed by cattle rotation, with the use of fire only to control eventual pests, 168 mechanical removal of invasive trees, and at least one record of liming 15 years before the 169 sampling. Soils sampled varied from average clay to sandy texture.

171 Forest was sampled as a model of a conservation area and the pasture chosen is in a small 172 property in Belterra, PA. The pasture used here was established between 1989-1994 and 173 supported cattle at the time of sampling, had sparse signs of degradation, fire was applied 174 when necessary to control invasive plants, and it has no history of liming. Soils sampled 175 varied from average clay to sandy texture. 
During each expedition, we sampled $20-30 \mathrm{~kg}$ of soil from the upper 0-10 cm layer of 5 equidistant sampling points along a linear gradient of $200 \mathrm{~m}$ at each site, from areas under Primary Forest and Pastures with Urochloa brizantha cv. Marandu. The sampled soils were transported to the Cell and Molecular Biology Laboratory at the University of Sao Paulo, CENA-USP, with fresh samples for chemical analysis and greenhouse experiments, or were frozen at the end of each sampling day and stored at $-20^{\circ} \mathrm{C}$ for future molecular analyses.

\section{Field Study}

At two pastures in the Tapajós region, $100 \mathrm{~m}$ side squares were established and 4 points in the square corners, plus a point in the center, were selected to evaluate $\mathrm{CH}_{4}$ fluxes at the time, and prior to gas flux measurements with static gas collection chambers the grass leaves were cut to their stems (2 cm above soil surface) and removed. Following chamber removal, the roots were collected, and the rhizospheric soil was sampled and stored at -20 ${ }^{\circ} \mathrm{C}$. Adjacent to each of the five sampling points we had selected, one square meter large areas without grass (bare soil) we used to measure methane fluxes and to collect soil samples for molecular and chemical analysis.

\section{Greenhouse experiments}

Sampled soil was homogenized, sieved $(5 \mathrm{~mm})$, and placed in clay pots with a capacity of 10 liters, resulting in $10 \mathrm{~cm}$ high soil columns with $5 \mathrm{~kg}$ of soil per pot. The grass was raised from seed in a subsample of the soil, and mature plants were transferred to the experimental clay pots at least 40 days after soil liming. The liming was performed by the addition of $\mathrm{CaCO}_{3}$ to reach pH 6.5 (water), calculated for a base saturation of 70-75\%. For each treatment, four

200 pots were used to grow Urochloa brizantha cV. Marandu with 4 additional pots as no-plant 201 controls (bare soil), both at natural pH and with limed soils (4 pots $\times 2$ soil types $\times 2 \mathrm{pH}$ 202 situations $\times 2$ plant situations). At the beginning of the experiment soil moisture was 203 standardized to $\sim 70 \%$ of the water retention capacity of the soil and adjusted every two to 204 four days, taking as reference the weight variation after drying soil samples for $48 \mathrm{~h}$ at $75^{\circ} \mathrm{C}$. 205 In the experiment with soil from Ariquemes, the plants were removed when they reached 206 approximately $35 \mathrm{~cm}$ in height, and by shaking and with the help of a sterilized brush the 
207 rhizosphere soil was collected. Here we defined the rhizosphere as soil that remained

208 attached to the roots even after vigorous plant shaking.

\section{Determination of methane fluxes in soil}

The measurements of $\mathrm{CH}_{4}$ fluxes in both the field sampling sites and the greenhouse

experiments were carried out using static gas collection chambers $(20 \mathrm{~cm}$ in diameter, $\sim 6 \mathrm{~L}$

213 inner volume). Over a period of 10 minutes measurements were taken at 10 second intervals

214 using a portable gas analyzer (UGGA, Los Gatos Research, San Jose, CA, USA). Daily flux

215 of gases was estimated from the concentration in the chamber headspace. Daily flux (F, mass

216 of gas $\mathrm{m}^{-2}$.day ${ }^{-1}$ ) was computed as (Ussiri, Lal and Jarecki, 2009):

$$
\mathrm{F}=\Delta \mathrm{gas} / \Delta \mathrm{t} \times \mathrm{V} / \mathrm{A} \times \mathrm{k}
$$

Where $\Delta g a s / \Delta t$ is the rate of change in $\mathrm{CH}_{4}$ concentration inside the chamber (i.e. $\mathrm{mg}$

$\left.221 \mathrm{CH}_{4}-\mathrm{C}\right) ; V$ is the chamber volume $\left(\mathrm{m}^{3}\right) ; A$ is the surface area circumscribed by the chamber

$222\left(\mathrm{~m}^{2}\right)$ and $k$ is the time conversion factor $\left(1440 \mathrm{~min} \mathrm{day}^{-1}\right)$. The cumulative gas emissions were 223 calculated by linear interpolation of average emissions between two successive 224 measurements and the sum of the results obtained over the entire study period. Finally, the 225 data was expressed as differences in the cumulative $\mathrm{CH}_{4}$ fluxes in relationship to the controls. 226 From this, we subtracted from the accumulated fluxes in the respective treatments (liming, 227 grass coverage, and liming plus grass coverage) the control measurements of the average 228 accumulated flux (bare soils).

\section{Characterization of soil chemical properties}

231 About $600 \mathrm{~g}$ of soil were analyzed for their physical-chemical properties at the 232 Laboratory of Chemical Analysis in the Soil Science Department at the "Luiz de Queiroz 233 School of Agriculture" (ESALQ / USP) (detailed in van Raij et al., 2001). The soil attributes 234 measured were: $\mathrm{pH}$ in $\mathrm{CaCl}_{2}$; concentrations of phosphorus, potassium, calcium, and 235 magnesium by extraction with ion exchange resin; aluminum by extraction of potassium 236 chloride at $1 \mathrm{~mol} / \mathrm{L}$; potential acidity estimated by $\mathrm{pH}$ - SMP buffer test; organic matter by the 237 dichromate- titrimetric method; boron by extraction with hot water; copper, iron, manganese 
238 and zinc extracted by the DTPA-TEA extractor ( $\mathrm{pH} \mathrm{7.3);} \mathrm{and} \mathrm{by} \mathrm{calculating} \mathrm{the} \mathrm{sum} \mathrm{of} \mathrm{bases}$

239 (BS); cation exchange capacity (CEC); base saturation (V\%), and aluminum saturation (m\%).

241 DNA extraction

242 DNA was extracted for molecular analyses from greenhouse soils that originated in 243 Ariquemes and Belterra (Tapajós region) and from soils of the field study in the Tapajós 244 regions. Total DNA was extracted from soil samples using the PowerLyzer PowerSoil DNA 245 Isolation Kit (Qiagen, Hilden, Germany) from $250 \mathrm{mg}$ of soil, according to the protocol 246 provided by the manufacturer, except that after adding solution C1 the stirring time was extended to 15 minutes followed by 3 min centrifugation (Venturini et al., 2020). The amount and quality of the DNA extracted was analyzed in a Nanodrop 2000c spectrophotometer

249 (Thermo Fisher Scientific, Waltham, MA, USA) at an optical density of $260 \mathrm{~nm}$. The total DNA extracted was stored at $-20^{\circ} \mathrm{C}$.

\section{Abundance of methane producers and oxidizers}

Real-time quantitative PCR (qPCR) was used to quantify the genes associated with methane cycling mcrA and pmoA (Table S1) in total soil DNA samples. For each gene, a the gene. Target genes were previously obtained by PCR from genomic DNA of Methanolinea mesofila (DSMZ 23604) for the mcrA gene, and Methylosinus sporium (DSMZ 17706) for the 258 gene pmoA, both obtained from the DSMZ (German Collection of Microorganisms and Cell 259 Cultures). The qPCR was performed in triplicate for each sample on a StepOne Plus cycler 260 (Thermo Fisher Scientific, Walthman, MA, USA), with a final volume of $10 \mu \mathrm{L}$, containing $5 \mu \mathrm{L}$ 261 of SYBR Green ROX qPCR (Thermo Fisher Scientific, MA, USA), $1 \mu \mathrm{L}$ of each primer (5 262 pmols), $1 \mu \mathrm{L}$ of soil DNA (adjusted to $10 \mathrm{ng} / \mu \mathrm{L}), 0.8 \mu \mathrm{L}$ of bovine albumin $(20 \mathrm{mg} / \mathrm{mL}$ ) 263 (Sigma-Aldrich, San Luis, MO, USA), and $1.2 \mu \mathrm{L}$ of ultrapure water (Milli-Q, autoclaved).

In order to minimize bias in the analysis between each qPCR plate run, gene 265 abundance was quantified with the software LinRegPCR (Ramakers et al., 2003). Raw 266 amplification data for each sample were used to calculate individual reaction efficiencies, and 267 detection limits were established for each group of technical replicates. The data generated in 268 arbitrary fluorescence units were converted to the number of copies of the genes using linear 
269 interpolation between the known quantities in the standard curve (5 best points out of 7) and 270 the observed fluorescence measurements, using the curves of each plate as a reference for 271 the respective samples.

\section{Sequencing of 165 rRNA gene fragments}

The composition of the microbial community was determined with high throughput sequencing (MiSeq Illumina platform with a 600c kit) of the V4 region of the 16S rRNA gene at the Functional Genomics Center of Luiz de Queiroz College of Agriculture (Caporaso et al., 2011). The V4 region was amplified with the primers 515F (Parada et al., 2016) and 806R (Apprill et al., 2015). This sequencing strategy was selected to match the highly diverse soil environment and for the size of the paired-end reads (average $300 \mathrm{bp}$ ). Gene library preparation followed the conditions of $95^{\circ} \mathrm{C}$ for 3 minutes, followed by 25 cycles at $95^{\circ} \mathrm{C}$ for 30 seconds, $50^{\circ} \mathrm{C}$ for 30 seconds, $72^{\circ} \mathrm{C}$ for 30 seconds, and a final extension step at $72^{\circ} \mathrm{C}$ for 5 minutes. The DNA concentrations in the samples were adjusted to $10 \mathrm{ng} / \mathrm{uL}$ using a Nanodrop 2000c spectrophotometer and the PCR reactions with $2.5 \mu \mathrm{L}$ of 10x buffer, $1 \mu \mathrm{L}$ of $50 \mathrm{mM} \mathrm{MgCl}, 1 \mu \mathrm{L}$ of $10 \mathrm{mM}$ dNTPs, $0.5 \mu \mathrm{L}$ of $10 \mu \mathrm{M}$ Forward and Reverse Primers, $0.5 \mu \mathrm{L}$ of $5 \mathrm{U} / \mu \mathrm{L}$ Taq Platinum - PCR and water for PCR - $14 \mu \mathrm{L}$, in a total volume of $25 \mu \mathrm{L}$ per reaction. Subsequent DNA purification of the amplicon was performed using AMPure XP beads (Beckman Coulter, Brea, CA, USA) and verified on an agarose gel. In a similarly structured, second PCR the adapters were added, followed by another purification with AMPure XP beads and gel electrophoretic confirmation in agarose. The amplicon pool was normalized using quantification by qPCR with the KAPA Illumina quantification kit (Roche,

291 Basel, Switzerland). The computational processing of these data was performed using 292 QIIME2 2017.11 (Bolyen et al., 2019), with data quality control using the DADA2 tool 293 (Callahan et al., 2017), without clustering into OTUs, and taxonomic identification of the 294 sequences was performed using q2-feature-classifier (Bokulich et al., 2018) and the SILVA 295 v.128 99\% database (Quast et al., 2013). 


\section{Phylogenetic analyses}

Some amplification sequence variants (ASVs) grouped closest with the family Beijerinckiaceae. Since this family represents both methanotrophic and non-methanotrophic genera, we increased our phylogenetic resolution by analyzing phylogenetic trees containing only Beijerinckiaceae sequences that were created with two $16 \mathrm{~S}$ rRNA primer pairs. One set of primers targeted the region V4, between 515F (Parada et al. 2006) and 806R (Apprill et al. 2015), and a second set of primers targeted the V3/V4 region, between 341F and 805R (Herlemann et al., 2011). For this last pair, the amplification protocol was identical to that described above, except the annealing temperature for the second primer pair was $55^{\circ} \mathrm{C}$. The sequences were aligned, and trees were calculated using the software CLC Genomics Workbench 20.0 (QIAGEN, Aarhus, Denmark) at default parameters, and with a maximum likelihood model (PHYML function) with UPGMA (Unweighted Pair Group Method with Arithmetic mean) assuming common replacement frequencies to the bases (Kimura, 1980).

The robustness of the final trees was tested with 1000 bootstrap replications. Reference sequences for members of the Beijerinckiaceae family were obtained from the cured database RDP version 11 (Cole et al., 2014) based on the criteria of high-quality reads with a length greater than $1200 \mathrm{bp}$ and representing type strains. The only sequence available for the 16S rRNA gene of the methanotrophic bacterium USCa (Pratscher et al., 2018) was also added.

\section{Statistical analysis}

All comparative analyses between groups were performed with ANOVA followed by a Tukey Honestly Significant Difference (HSD) test and p-values calculated for a two-tailed distribution of the data using the package agricolae version 1.2-8 (R Core Team, 2013).

Significant explanatory variables of the methane fluxes were chosen by linear regression and model selection (backward) and by minimizing the Akaike Information Criterion (AIC). The statistical significance was assessed by 1000 permutations of the reduced model. The resulting significant explanatory variables were used to access their contribution to explain the $\mathrm{CH}_{4}$ fluxes, using the function varpart (Peres-Neto et al., 2016) in the vegan package (Oksanen et al., 2015). Statistical analyses were performed in R Studio software (R Core Team, 2013). 
The DEICODE tool (Martino et al., 2019) in the QIIME2 2019.10 was used to process the sequencing data. This tool can identify significant changes in the community based on

333 relative abundance data. Next, the software QURRO (Fedarko et al., 2019) was used to

334 assess shifts in the methane cycling community based on transformed abundance data 335 (natural logarithm) and using a minimum of 10 occurrences per taxon.

\section{Results}

This study tested the effect of acidity correction by liming and the presence of a grass cover by Urochloa brizantha cv. Marandu on soil methane fluxes with soils from pasture and 340 forest of different Amazon regions. Two greenhouse experiments were set up. The first 341 experiment was performed with soils from a western Amazon region (Ariquemes, RO) and the 342 second with soils from an eastern region (Tapajós, PA). In both experiments liming resulted in 343 a final $\mathrm{pH}$ of $\sim 6.0\left(\mathrm{CaCl}_{2}\right.$, equivalent to $\mathrm{pH} 6.5$ in $\left.\mathrm{H}_{2} \mathrm{O}\right)$, and an increase in calcium availability, 344 as well a decrease in aluminum saturation (Table S2). In the Ariquemes experiment, methane 345 was sink in both bare soils of forest and pasture at their respective natural $\mathrm{pH}$ values, with 346 greater uptake in forest soils (Figure 1). In the Tapajós experiment, we observed methane 347 emissions from bare soils from the pasture at natural $\mathrm{pH}$, and methane uptake in bare soils 348 from forest at natural $\mathrm{pH}$ (Figure S1). When forest soils from Ariquemes had grass cover they 349 exhibited the highest methane consumption (Figure 1-b; $p=0.059$ ), at values close to the 350 naturally acidic forest soil, but significantly lower than both limed soils with or without grass 351 cover (Figure 1-b). The Tapajós soils showed a similar trend compared to Ariquemes soils 352 (Figure S1). Methane uptake in pasture soils increase by 35\% on average when they have 353 grass coverage (Figure 1-a; $p=0.001$ ). However, liming of pasture soils reduced their 354 methane uptake (Figure 1-a; $p=0.001$ ) and turned forest soils from a methane sink into a 355 methane source (Figure S1-b; $p=0.052$ ). 
a) Pasture

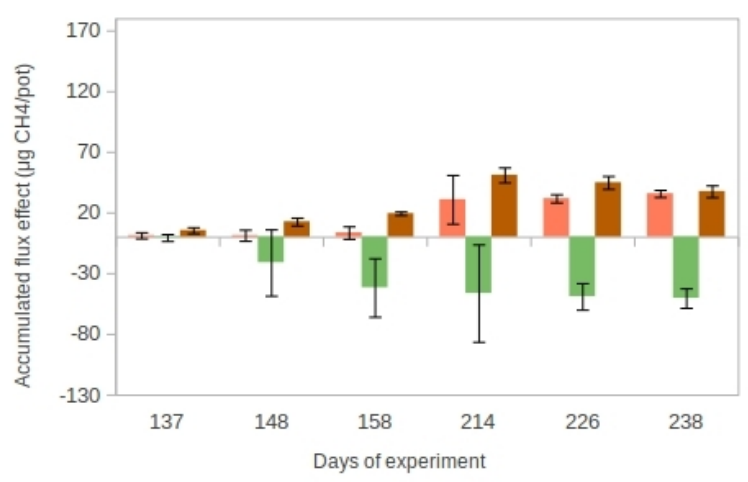

b) Forest

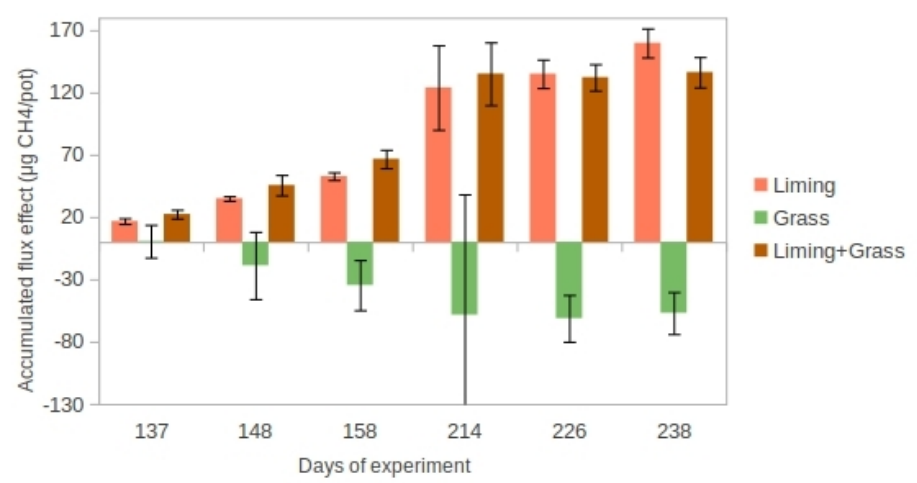

357

Figure 1: Differences in the accumulated methane flux effect compared to untreated control (bare soils at natural $\mathrm{pH}$ ) in a) pasture and b) forest soils from the Ariquemes experiment in western Amazonia, with and without acidity correction and with and without grass coverage. Bars show standard deviation.

The validity of our observation that, compared to exposed bare soils, grass coverage improves soil methane uptake was tested in the field. In situ measurements of $\mathrm{CH}_{4}$ fluxes were taken on two pastures in Belterra/PA, Tapajós region, during the end of wet season, at points with and without grass coverage. No significant differences were observed, but the trend is similar to that observed in the greenhouse experiments (Figure S2; $p=0.112$ ).

Molecular analyses were performed only with soils from the Ariquemes greenhouse experiment (Figure 2) and from the field study in the Tapajós region (Figure S3). The methane cycling microbiota was evaluated through quantification of their functional marker genes pmoA and mcrA, indicating methane consumers and producers, respectively (Figure 2). The rhizospheric community was evaluated only at the end of the experiment $(T 3=250$ days). During most of the experimental timeline, we did not observe differences in the abundance of methanotrophs between pasture and forest soils (Figure 2). Regarding methane producers, we observed very low abundance in forest soils compared to pasture soils during the experimental duration. The acidity correction shows a tendency to reduce methanotroph levels in forest soils after 250 days in the grass rhizosphere $(p=0.339)$ and in the bare soil $(p=0.162)$ (Figure $2 A)$. Pasture soils had between 100 and 1000 -fold more methanogenic archaea than forest soils throughout the experiment, which did not change with acidity correction (Figure 2B). The abundance of methanogenic archaea in the grass rhizosphere in pasture soils was reduced on average by 13 times compared to the bare soil 
381 (Figure 2B; $\mathrm{p}=0.025$ ). No significant changes of methanotrophs were recorded in the 382 rhizosphere (Figure $2 \mathrm{~A} ; \mathrm{p}=0.263$ ). This reduction in methanogenic archaea in the grass 383 rhizosphere was not observed in the field study (Figure S3; $p=0.186$ ).

$\begin{array}{ll}\text { A) } p m o A & \text { B) } m c r A\end{array}$
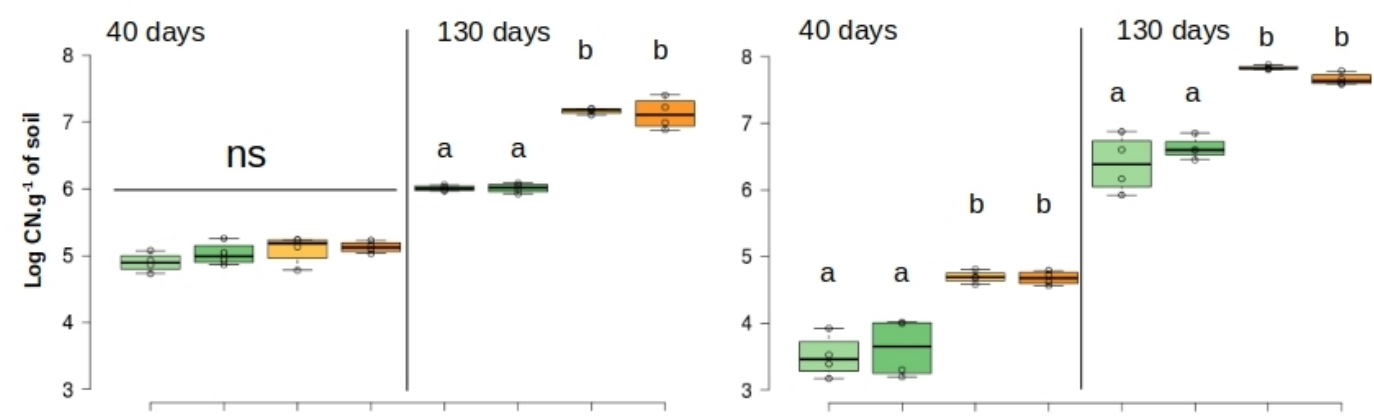

$\begin{array}{lll} & \text { Acidic-Bare soil } \\ \text { Ш } & \text { Liming-Bare soil } \\ \text { Ф } & \text { Acidic-Rhizospheric } \\ \text { 노 } & \text { Liming-Rhizospheric }\end{array}$
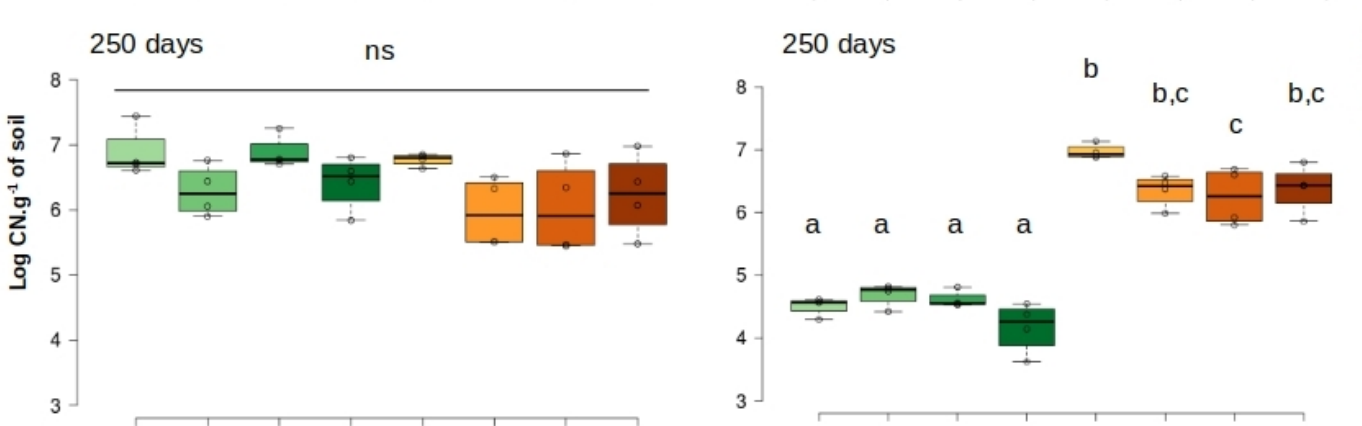

Acidic-Bare soil Liming-Bare soil Acidic-Rhizospheric Liming-Rhizospheric

Figure 2: Gene quantification of the genes (A) $p m o A$ and $(B) \operatorname{mcr} A$ at different times after the beginning of the Ariquemes experiment. T1 $=40$ days, $\mathrm{T} 2=130$ days and $\mathrm{T} 3=250$ days. Letters

To investigate the effects of acidity correction and grass rhizosphere on specific groups of microorganisms, high throughput DNA sequencing of the 16S rRNA gene was performed.

391 The results show fair sequencing depth, with rarefaction curves leveling off well below the 392 minimal sequencing depth in soils from the Ariquemes experiment (Table S3, Figure S4-a) 393 and in soils from the field studies (Table S4, Figure S4-b).

$394 \quad$ Considering only the community associated with methane cycling in the soil (identified 395 with a minimum of $90 \%$ confidence), we filtered the groups recognized as methanotrophs 396 (Knief, 2015) and methanogens (Evans et al., 2019) and observed results similar to those 397 obtained in the quantification of gene copies in total DNA. The number of methanogens in 398 forest soils was smaller, while the abundance of methanotrophs was similar between forest 
399 and pasture soils (Figure 3). The increase of methanogens in forest soils with acidity 400 correction was not significant. A significant drop in methanotroph abundance was observed 401 only for the combination of acidity correction and grass cover treatments (Figure 3, $p=0.024$ ). 402 Methanotrophs in pasture soils did not change with liming or with the presence of grass cover, 403 as previously observed in the quantification of pmoA gene copies (Figure 2). However, the 404 number of methanogens was significantly reduced in the grass rhizosphere, with $(p=0.017)$ or 405 without $(p=0.007)$ acidity correction (Figure 3$)$. This last result was similar to that observed in 406 the field, which, although not significant, points to a tendency to reduce methanogenic 407 archaea of different groups in the grass rhizosphere (Figure S5).

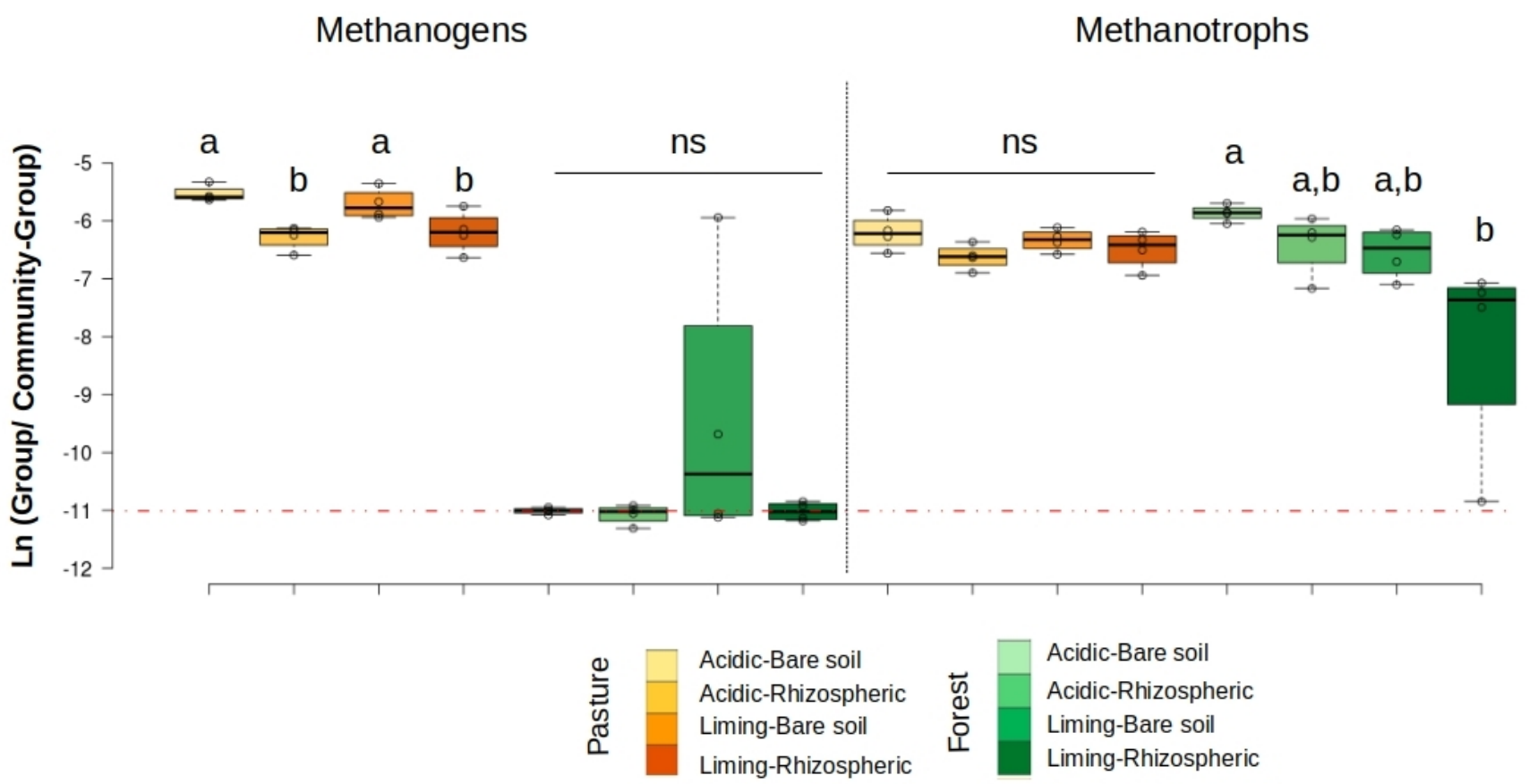

410 Figure 3: Changes in the logarithmic ratio between methanogenic and methanotrophic groups in 411 relation to the whole community (16S rRNA) in the Ariquemes experiment. The dotted line indicates a 412 calculated ratio of the minimum of 10 counts for each group. The more negative the number of the 413 natural log, the lower the abundance in relation to the total community. Letters indicate significant 414 changes within each treatment for the same land use and group of microorganisms (Tukey HSD; $p<$ 415 0.05). Ns = not significant. 
Finally, to understand which groups are associated with methane cycling in these soils,

418 a detailed analysis was performed of all groups that presented sequences of the genera 419 known to act in methane cycling (Knief, 2015; Angel et al., 2012) (Figures 4 and 5). In pasture 420 soils, the abundance of members of all methanogenic genera was lower when soil was grass 421 covered. Forest soils showed a low abundance of methanogenic archaea belonging to 422 Methanosarcina spp. The Beijerinckiaceae family is abundant in these soils but it was not 423 possible to identify the sequences at the genus level with the database SILVA v.128 (Quast et 424 al., 2012). A new phylogenetic identification was performed comparing all the sequences 425 annotated as Beijerinckiaceae in the RDP database, with the five amplification sequence 426 variants (ASVs) from sequencing with primers 341F/805R and 8 ASVs from primers 427 515F/806R. In this analysis, only sequences of the 16S rRNA gene of this family were used 428 as reference, and the results indicate that they are closely related to the methanotrophic 429 clade, with more than 90\% confidence (Figures S6 and S7). Those Beijerinckiaceae are 430 reduced in their relative abundance in forest soils with acidity correction (Figure 5), without 431 changes in pasture. No significant changes were observed in relation to other methanotrophs.
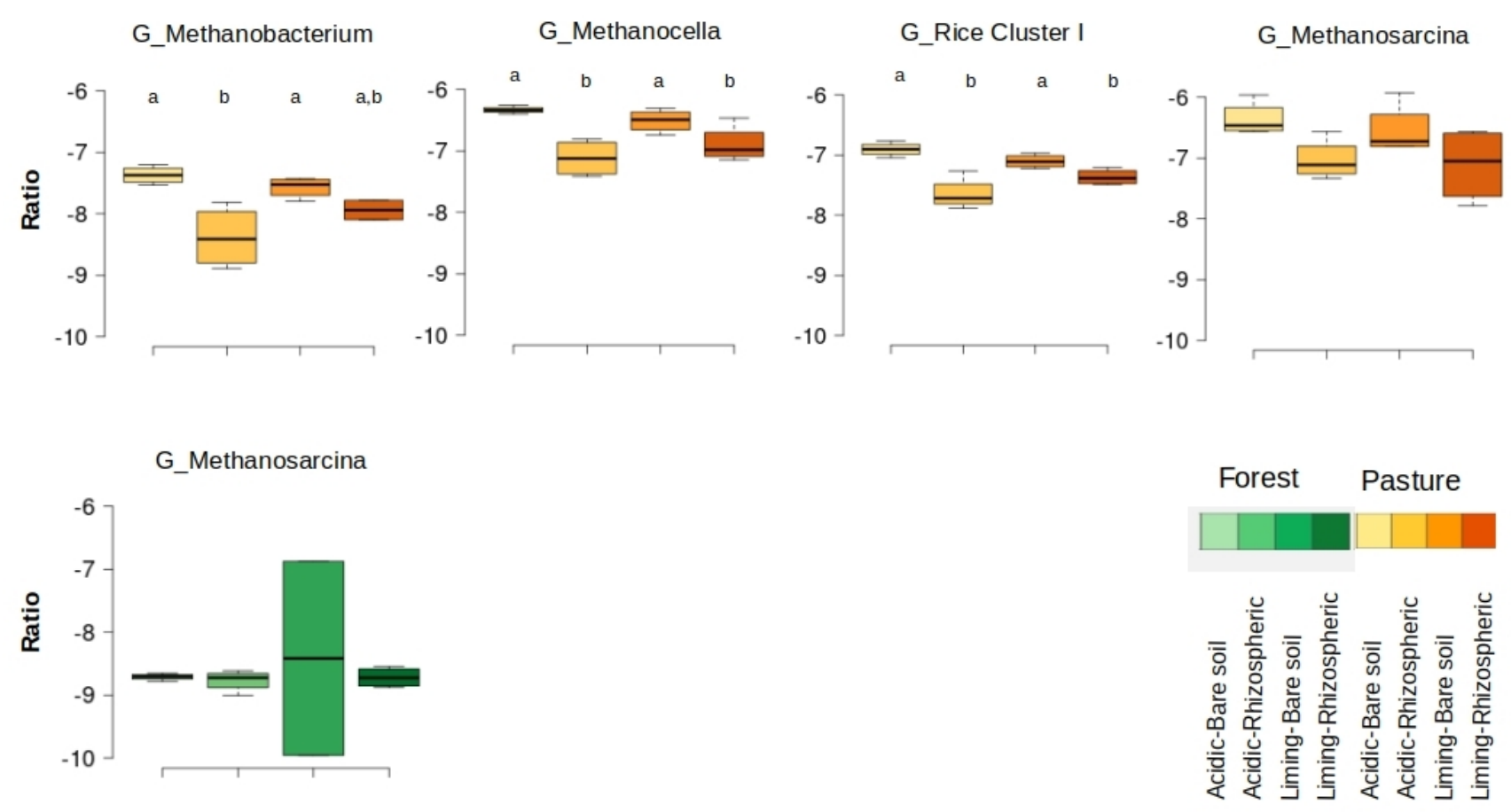
434 Figure 4: Changes in the $\log _{\mathrm{e}}$ ratio between methanogenic microorganisms by genus (G) in relation to 435 the total community in the Ariquemes experiment. All the identified genera are shown. The more 436 negative the numbers, the lower the abundance. Letters indicate significant differences (Tukey HSD; $437 \mathrm{p}<0.05)$
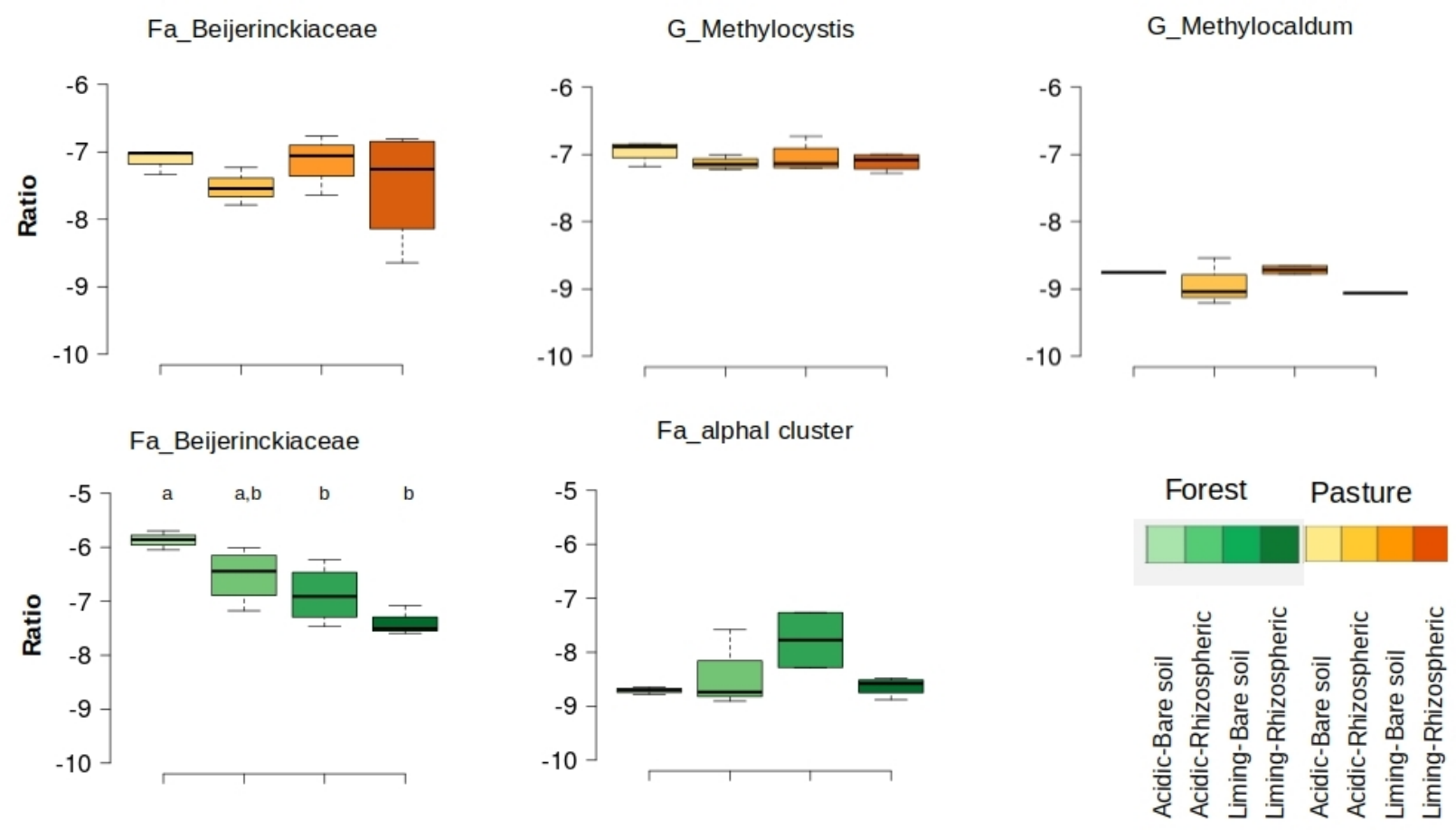

441 Figure 5: Changes in the $\log _{\mathrm{e}}$ ratio between methanotrophic microorganisms by genus (G) or family 442 (Fa) in relation to the total community in the Ariquemes experiment. The more negative the numbers, 443 the lower the abundance. Letters indicate significant differences (Tukey HSD; $p<0.05$ ). Analysis showed that a large part of the explained variation (67\%) was due to the joint affects.

447 grass on the $\mathrm{CH}_{4}$ fluxes we performed a variation partitioning analysis. This analysis showed 448 that a large part of the explained variation of the methane fluxes (40\%) was due to $\mathrm{pH}$ and 449 other soil properties in the first days of the experiment (Figure 6b). However, the grass 450 biomass represented most of the explained variance at the later time-points (Figure 6e-f). The 451 effect of methanogen and methanotroph abundance was minor in the beginning of the 452 incubation (6\%) but reached $13 \%$ of explained variance at the last time point. These results 
457 indicate that the $\mathrm{CH}_{4}$ fluxes vary through time and are driven by dynamic factors. Here we

458 decided to separate $\mathrm{pH}$ from other soil properties when running this analysis as $\mathrm{pH}$ has been 459 previously shown to be a major driver in $\mathrm{CH}_{4}$ soil fluxes. Our results confirm this as in the 460 beginning of the experiment the $\mathrm{pH}$ and other soil physical-chemical properties were the 461 stronger explanatory variables of the $\mathrm{CH}_{4}$ uptake capacity (Table 1). However, the 462 contribution of the soil properties decreases through time while the presence of the grass and 463 the microbial communities gain in explanatory power.

(a) Outline

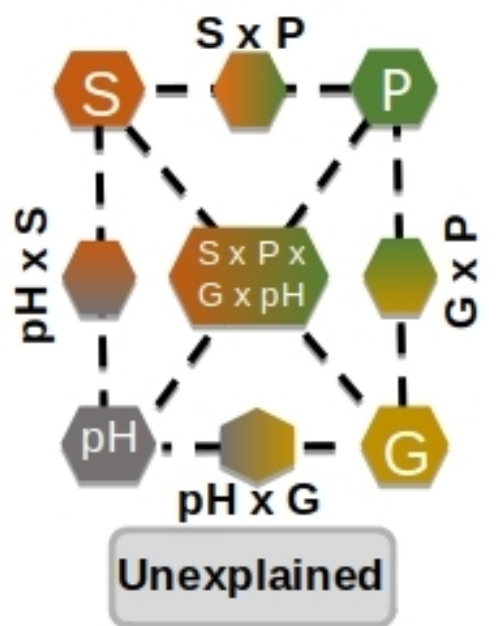

(d) 28-84 day

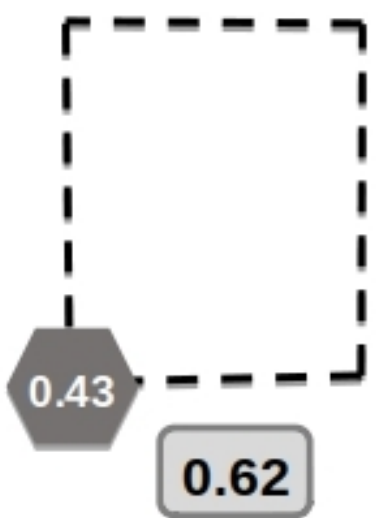

(b) 0-7 day

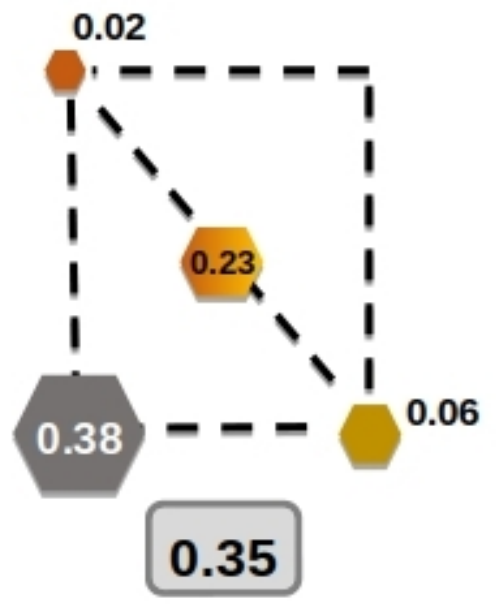

(e) 84-96 day

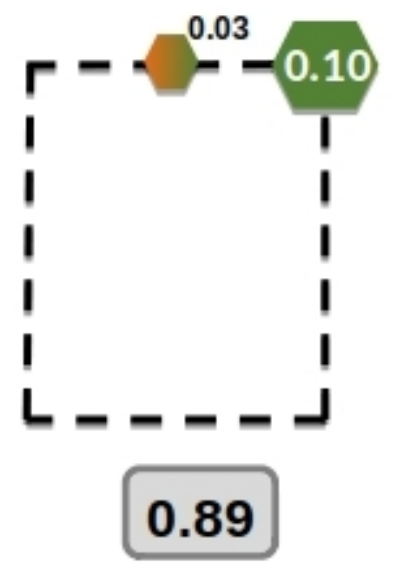

(c) $\mathbf{1 8 - 2 8}$ day

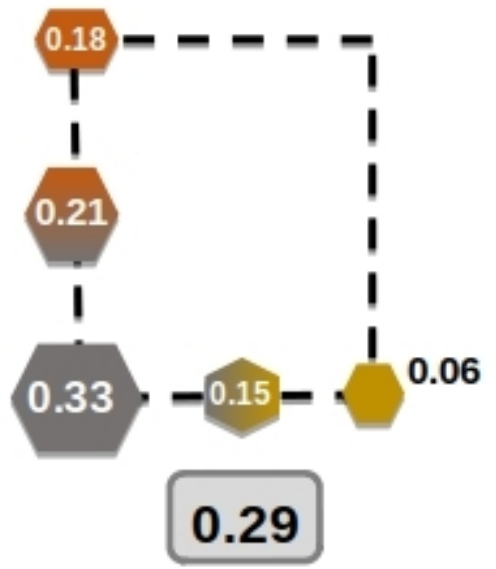

(f) 96-108 day

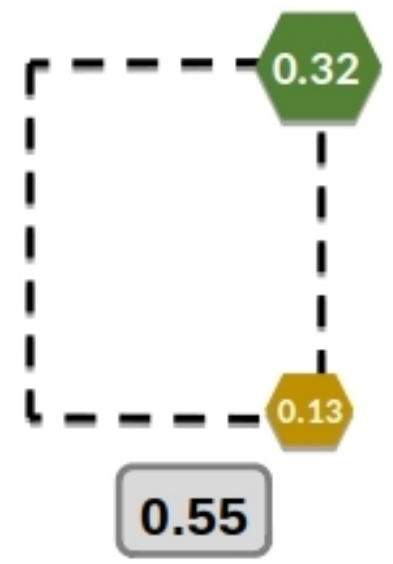


466 Figure 6: Variation partitioning analysis to determine the drivers of $\mathrm{CH}_{4}$ fluxes in the Ariquemes soils in time intervals from day 0 to day 7 (b), day 18 to 28 (c), 28-84 (d), 84-96 (e), and 96-1-8 (f). Variance was partitioned into four explanatory variables, soil physical-chemical properties (S), $\mathrm{pH}$, abundance of methanotrophs and methanogens $(G)$, plant biomass $(P)$, and by combinations of these potential predictors as exemplified in the outline (a). Geometric areas are proportional to the respective percentages of explained variation. The corners of the square depict the variation explained by each factor alone, while percentages of variation explained by interactions of two or all factors are indicated on the sides and in the middle of the square, respectively. All numbers represent percentages, graphically represented by the size of the respective hexagons. Only variance fractions $\geq 2 \%$ are shown. The variables used for each variation partitioning are indicated in Table 1.

Table 1. Selected explaining variables for the capacity of methane consumption determined with the variation partitioning analyses at five different time-intervals during the Ariquemes experiment.

\begin{tabular}{|c|c|c|c|}
\hline $\begin{array}{l}\text { Time } \\
\text { interval }\end{array}$ & $\begin{array}{c}\text { Soil properties }^{a} \\
\& \mathrm{pH}\end{array}$ & $\begin{array}{c}\text { Gene } \\
\text { abundances }\end{array}$ & Plant $^{b}$ \\
\hline $0-7$ & $\begin{array}{c}\mathrm{pH}, \mathrm{OM}, \mathrm{Cu}, \\
\text { CEC }\end{array}$ & $m r c A$ & NA \\
\hline $18-28$ & $\mathrm{pH}, \mathrm{Cu}$ & pmoA & NA \\
\hline $28-84$ & $\mathrm{pH}, \mathrm{CEC}$ & - & NA \\
\hline $84-96$ & - & - & Plant biomass \\
\hline $96-108$ & - & mcrA & Plant biomass \\
\hline
\end{tabular}




\section{Discussion}

Deforestation of the Amazonian forest often followed by the establishment of pastures.

488 This forest-to-pasture conversion affects soil methane cycling, where forest soils that were 489 previously acting as a methane sink now become sources of methane (Fernandes et al., 490 2002). This study confirms previous field results (Meyer et al., 2020; Fernandes et al., 2002; 491 Goreau; De Mello, 1988; Steudler et al., 1996), although the values obtained in our 492 experiments cannot be directly compared to those reported, since the results are limited to a $49310 \mathrm{~cm}$ surface layer of soil. The trend observed is the same recorded by Steudler et al. 494 (1996), in that forests consume 2.74 more methane than pastures. In our experiments, these 495 values were 0.6-fold in soils from Ariquemes in western Amazonia, and 4.28-fold in soils from 496 Tapajós in eastern Amazonia. This discrepancy may be related to differences in soil 497 microbial communities and chemical properties, but it can also be a consequence of conservation of the forest areas from which these soils originated. While in Ariquemes forests were fragmented and small samples from Tapajós originated from a contiguous forest in a 500 conservation area. Forest fragmentation is known to be associated with increased 501 greenhouse gas emissions (Laurance et al., 1998). Furthermore, the pastures sampled in 502 Ariquemes/RO have a history of long-term management, and the pasture soils sampled in 503 Belterra/PA showed signs of degradation. As management affects the carbon stock in the soil 504 (Fearnside \& Imbrozio Barbosa, 1998), it can be expected that it will also affect methane 505 cycling in the soil.

506 The forest-to-pasture conversion alters the physical-chemical properties of the soil, 507 with consequences to microorganisms that produce and consume methane. In field studies in 508 the same region in Ariquemes, a decrease in methanotrophic bacteria and an increase in 509 methanogenic archaea were observed, in addition to changes in the composition of 510 communities, which were attributed at least in part to changes in methane fluxes (Meyer et 511 al., 2017, Meyer et al. 2020). Also, an increase in activity of methanogens in pastures, 512 compared to forest soils, was recorded in soils from the same region (Kroeger et al. 2020).

513 Our results under controlled moisture conditions did not detect significant changes in the 514 methanotrophic community nor changes in the relative abundance of specific methanotrophic 515 groups. However, there was a significant increase in the abundance of methanogenic 516 archaea in pastures compared to forest soils. These results indicate that studies of the 
517 microbiota associated with methane cycling should consider the seasonality of rainfall in the

518 field to better understand the system, such as that developed by Fernandes et al. (2002).

519 Pasture soils in the Amazonian region present a microbial community quite distinct 520 from that observed in forest soils (de Carvalho et al., 2016; Rodrigues et al., 2013; Jesus et 521 al., 2009). This is partly attributed to acidity reduction in the process of establishing pastures. 522 Forest soils in Amazonia have $\mathrm{pH}\left(\mathrm{H}_{2} \mathrm{O}\right)$ values between 3.5 to 4.5 (Demattê and Demattê, 523 1993). The $\mathrm{pH}$ is currently understood as one of the main drivers of microbial community 524 structure in soils (Fierer \& Jackson, 2006), and increasing it by liming is a strategy to improve 525 fertility and reduce soil toxicity to plants (Oliveira et al., 2013). This process becomes 526 necessary in pasture management to counter the tendency for acidification of pasture soils over time with soil $\mathrm{pH}$ reaching values close to those observed in forest areas (de Moraes et al., 1996). In addition, degraded pastures, which can amount to more than $50 \%$ of pasture areas in Amazonia (Dias-Filho, 2017), also tend to need acidity correction for their restoration. tropical soils. It is known that the optimum growth $\mathrm{pH}$ of most cultivable methanotrophs and methanogens is neutral (Le Mer \& Roger, 2001; Whittenbury et al., 1970), which is why soil $\mathrm{pH}$ represents an important explanatory variable for the distribution of methanotrophs.

534 However, methane oxidation is observed in natural environments across a wide $\mathrm{pH}$ range 535 (Knief et al., 2003; Kolb, 2009; Nazaries et al., 2013). Our results indicate that the soil acidity correction for $\mathrm{pH}\left(\mathrm{H}_{2} \mathrm{O}\right)$ values close to 6.5 has different effects in pasture or forest soils, 537 possibly because the forest soil has undergone a more intense $\mathrm{pH}$ correction, starting at 3.55385.0 and finishing at 6.5, while in pasture soils the change was from 4.5-5.5 to 6.5. In our forest 539 soils from Ariquemes, we determined a decrease in methane uptake in response to liming, 540 and a shift from uptake to emission in forest soils from Tapajos. Yet, no significant differences 541 were noticed in pasture soils. Thus, liming pasture soils may not impact methane emissions, 542 but still help to maintain the $\mathrm{pH}$ of these soils at values suitable for grass biomass 543 productivity. For forest soils, we have shown that the reduction in acidity alone is enough to 544 shift the soil from a methane sink to a source. This change in methane fluxes was not 545 noticeable in the abundance of methanotrophic or methanogenic microorganisms by qPCR, 546 despite a reduction in the relative abundance of methanotrophs that follows the acidity 547 correction. 

gene, such as those generated in this study, is limited to the evolutionary information available in that fragment so that it is not always feasible to identify the microorganisms at the genus level. Considering that the ability to oxidize methane is variable at the genus level in they are methanotrophs. This family also includes generalist bacteria capable of using 554 multiple carbon compounds as an energy source, and here Beijerinckiaceae are more abundant in forest soils than in pastures. Thus, identifying whether they are methanotrophs or not is relevant to understand methane cycling in the forest-to-pasture conversion. The results demonstrate that the Beijerinckiaceae sequences observed in forest soils cluster together in phylogenetic trees. This cluster was observed on the two data sets with high support (> 90\% in 1000 bootstraps) and also includes the methanotrophic USCa, which indicates that these sequences are potential methanotrophic Beijerinckiaceae.

The differences observed in methane fluxes after liming were not noticed in the abundance of producers and consumers. This discrepancy might be related to a reduction in 563 the activity of forest soil to act as a methane sink after acidity correction, due to the lower 564 availability of $\mathrm{Fe}$ and $\mathrm{Cu}$ which are necessary as cofactors for the activity of methane565 monooxygenase (Semrau et al., 1995). Alternatively, this discrepancy might be due to 566 limitations of the primers, drawn mostly with microbial references from temperate soils, but we 567 applied them to tropical soils. Or, the difference between methane flux and shift in abundance 568 of methane cycling microorganisms can be due to ammonia oxidizers, possibly oxidizing 569 methane at a higher soil $\mathrm{pH}$. We believe that methanotrophs are the group that was affected 570 the most, since acidity correction was followed by a reduction in the consumption of 571 atmospheric methane by the soil (concentrations of $\sim 1.8 \mathrm{ppm}$ ). Also, the duration of 572 incubating soil from Ariquemes for 250 days should be long enough to observe compensatory 573 changes due to DNA replication, that should be detected in the DNA quantification analysis.

$574 \quad$ Although there is great natural variability in the methane flux data, the final averages 575 led to the conclusion that pasture soils act as a methane source, which is in fact a commonly 576 reported final result. This observed variability means that pastures could seasonally or by 577 location switch from being a methane source to temporarily becoming a methane sink 578 (Fernandes et al., 2002; Steudler et al., 1996). Our initial hypothesis was that the methane 
579

consuming capacity of pasture soils would be related to intermediate moisture availability in the micro-environments of soil, since soil moisture is a determining factor for methane fluxes in pastures (Verchot et al., 2000). To eliminate moisture variation as a variable in the experiments we set the soil water contents at $70 \%$ of the holding capacity in the greenhouse experiments. The variability of pasture gas fluxes could also be explained by grass coverage, a factor associated with pasture management. The management of pastures can influence soil gas fluxes (Figueiredo et al. 2017), since it influences the carbon stocks in the soil (Fearnside \& Imbrozio Barbosa, 1998), however the way ongoing pasture management can affect the microbial community remains an open question. Considering that management is performed with the goal of grass productivity, and greater aerial biomass is associated with greater root biomass, we expect that a larger root surface area in pasture would create a more interactive environment with the soil microbiota, and thus enable higher rhizosphere activity. The role of the rhizosphere on methane cycling in upland soils is still poorly understood, and even different plant species can influence the soil by increasing methane oxidation or production, depending on the type of soil or soil conditions (Praeg et al., 2017). In soils of the Ariquemes experiment, we observed that plant cover will lead to a reduced methane flux in both forest and pasture soils compared to those with acidity correction. The methane flux rates with grass cover were similar to those of the original forest soil and tended to be higher than those of pasture without acidity correction. In soils from Tapajós experiment, the same trend was observed in forest soils, but possible due to the shorter duration of this experiment, there were no significant differences in the pasture.

When disentangling the contribution of different biotic and abiotic factors to $\mathrm{CH}_{4}$ soil uptake capacity we found that its drivers change through time, which could explain as previously discussed that soils might change from a source to a sink. While $\mathrm{pH}$ and other soil properties explained most of the variance in the beginning of the greenhouse experiment, the abundance of microbial communities related to $\mathrm{CH}_{4}$ fluxes and plant biomass explained most of the $\mathrm{CH}_{4}$ uptake at the end of the experiment. These results suggests that our treatments (liming and planting grass) are causing a reorganization of the microbial communities and while the soil properties are initially the main variables explaining the $\mathrm{CH}_{4}$ fluxes, after a couple of weeks the biotic factors are the main drivers of $\mathrm{CH}_{4}$ fluxes in these soils. While a previous study showed that peak emissions of the green-house gas $\mathrm{N}_{2} \mathrm{O}$ can be driven by the 
610 microorganisms related to the production and reduction of this green-house gas (Domeignoz-

611 Horta, et al., 2017), our results show how microorganisms related to methane cycling and 612 plant cover play a role to understand the temporal dynamics of $\mathrm{CH}_{4}$ uptake in soils. These 613 results highlight the need for better characterizing microbial communities to increase our 614 understanding of the relationship between abundance and diversity of microorganisms and 615 their corresponding processes.

The results presented here demonstrate that soil acidity is an important factor for 617 methane sequestration in tropical soils, as the acidity correction reduces this capacity. In 618 pastures, the effect of the acidity correction is less consequential compared to the presence 619 of grass coverage. This demonstrates that the correction of acidity in pastures, if combined 620 with constant soil coverage with grass, would have little or no impact on methane emissions 621 while improving soil structure and increasing nutrient availability, soil organic matter and grass 622 productivity.

623

\section{Conclusion}

625 Our results suggest that the impact of methane emissions from pastures in the 626 Amazonian region can be mitigated through pasture management, specifically by keeping the 627 soil always covered with grass. The rhizosphere of Urochloa brizantha cv. Marandu affects 628 soil microbial communities by lowering the abundance of methanogenic archaea up to 10 629 times compared to the bare soil. The affected methanogens are composed of 630 Methanobacterium spp., Methanocella spp., Rice Cluster I, and Methanosarcina spp. In 631 addition, we demonstrate that the correction of acidity in pasture soils can reduce methane 632 sequestration under atmospheric methane concentrations (high-affinity methanotrophs).

633 Therefore, the level of acidity correction should be considered as a factor for additional 634 emissions of greenhouse gases. In the acidic forest soils, an increase in $\mathrm{pH}$ reduced methane 635 sequestration by more than $50 \%$, thereby reversing the flux direction to turn forest soil from a 636 methane sink into a source. Field studies with liming and a focus on the grass rhizosphere 637 under seasonal conditions are urgently needed to provide specific recommendations to 638 policymakers and farmers. 


\section{Acknowledgments}

642 The authors thank the owners and staff of Farm "Fazenda Nova Vida", for logistical 643 support and permission to work on their property. We also thank the private landowners:

644 Aristeu, Bernardo e Elói for their support and access to their land. We would like to thank the 645 Large-Scale Biosphere-Atmosphere Program (LBA), coordinated by the National Institute for 646 Amazon Research (INPA), for the use and availability of data for logistical support and 647 infrastructure during field activities. Additionally, we are grateful to Prof. Plinio B. de Camargo, 648 Henrique Cipriani (EMBRAPA-RO), Alexandre Pedrinho, and to Wagner Piccinini for 649 assistance with fieldwork.

650

651 Funding. This project was supported by the BIOTA FAPESP and NSF - Dimensions of 652 Biodiversity (2014/50320-4 and DEB 1442183) and by CNPq (311008/2016-0). Additional 653 funding in the form of scholarships were provided by FAPESP (2018/09117-1), CNPq 654 (140953/2017-5), and CAPES (001 and 88881.189492/2018-01). 


\section{References}

656 Angel, R., Claus, P., \& Conrad, R. (2012). Methanogenic archaea are globally ubiquitous in aerated soils and become active under wet anoxic conditions. The ISME Journal, 6(4), 847-862. https://doi.org/10.1038/ismej.2011.141

Apprill, A., McNally, S., Parsons, R., \& Weber, L. (2015). Minor revision to V4 region SSU rRNA 806R gene primer greatly increases detection of SAR11 bacterioplankton. Aquatic Microbial Ecology, 75(2), 129-137. https://doi.org/10.3354/ame01753

Barton, L., Murphy, D. V., \& Butterbach-Bahl, K. (2013). Influence of crop rotation and liming on greenhouse gas emissions from a semi-arid soil. Agriculture, Ecosystems \& Environment, 167, 23-32. https://doi.org/10.1016/j.agee.2013.01.003

Bižić, M., Klintzsch, T., Ionescu, D., Hindiyeh, M. Y., Günthel, M., Muro-Pastor, A. M., Eckert, W., Urich, T., Keppler, F., \& Grossart, H.-P. (2020). Aquatic and terrestrial cyanobacteria produce methane. Science Advances, 6(3), eaax5343. https://doi.org/10.1126/sciadv.aax5343

Bokulich, N. A., Kaehler, B. D., Rideout, J. R., Dillon, M., Bolyen, E., Knight, R., Huttley, G. A., \& Gregory Caporaso, J. (2018). Optimizing taxonomic classification of marker-gene amplicon sequences with QIIME 2's q2-feature-classifier plugin. Microbiome, 6(1). https:// doi.org/10.1186/s40168-018-0470-z

Bolyen, E., Rideout, J. R., Dillon, M. R., Bokulich, N. A., Abnet, C. C., Al-Ghalith, G. A., Alexander, H., Alm, E. J., Arumugam, M., Asnicar, F., Bai, Y., Bisanz, J. E., Bittinger, K., Brejnrod, A., Brislawn, C. J., Brown, C. T., Callahan, B. J., Caraballo-Rodríguez, A. M., Chase, J., ... Caporaso, J. G. (2019). Reproducible, interactive, scalable and extensible microbiome data science using QIIME 2. In Nature Biotechnology (Vol. 37, Issue 8, pp. 852-857). Nature Publishing Group. https://doi.org/10.1038/s41587-019-0209-9

Borken, W., \& Brumme, R. (1997). Liming practice in temperate forest ecosystems and the effects on CO2, N2O and $\mathrm{CH} 4$ fluxes. Soil Use and Management, 13, 251-257. https://doi.org/10.1111/j.1475-2743.1997.tb00596.x

Bustamante, M. M. C., Nobre, C. A., Smeraldi, R., Aguiar, A. P. D., Barioni, L. G., Ferreira, L. G., Longo, K., May, P., Pinto, A. S., \& Ometto, J. P. H. B. (2012). Estimating greenhouse gas emissions from cattle raising in Brazil. Climatic Change, 115(3-4), 559-577. https://doi.org/10.1007/s10584-012-0443-3 
686 Butterbach-Bahl, K., Rothe, A., \& Papen, H. (2002). Effect of tree distance on N2O and CH4-

fluxes from soils in temperate forest ecosystems. Plant and Soil, 240(1), 91-103. https://doi.org/10.1023/A:1015828701885

Caporaso, J. G., Lauber, C. L., Walters, W. A., Berg-Lyons, D., Lozupone, C. A., Turnbaugh, P. J., Fierer, N., \& Knight, R. (2011). Global patterns of 16S rRNA diversity at a depth of millions of sequences per sample. Proceedings of the National Academy of Sciences of the United States of America, 108 Suppl 1(Supplement 1), 4516-4522. https://doi.org/10.1073/pnas.1000080107

Cole, J. R., Wang, Q., Fish, J. A., Chai, B., McGarrell, D. M., Sun, Y., Brown, C. T., PorrasAlfaro, A., Kuske, C. R., \& Tiedje, J. M. (2014). Ribosomal Database Project: data and tools for high throughput rRNA analysis. Nucleic Acids Research, 42(Database issue), D633-D642. https://doi.org/10.1093/nar/gkt1244

Costello, A. M., \& Lidstrom, M. E. (1999). Molecular Characterization of Functional and Phylogenetic Genes from Natural Populations of Methanotrophs in Lake Sediments. Applied and Environmental Microbiology, 65(11), 5066-5074. http://aem.asm.org/content/65/11/5066

de Carvalho, T. S., Jesus, E. da C., Barlow, J., Gardner, T. A., Soares, I. C., Tiedje, J. M., \& Moreira, F. M. de S. (2016). Land use intensification in the humid tropics increased both alpha and beta diversity of soil bacteria. Ecology, 97(10), 2760-2771. https://doi.org/10.1002/ecy.1513

de Moraes, J. F. L., Volkoff, B., Cerri, C. C., \& Bernoux, M. (1996). Soil properties under Amazon forest and changes due to pasture installation in Rondônia, Brazil. Geoderma, 70(1), 63-81. https://doi.org/10.1016/0016-7061(95)00072-0

Demattê, J. L. I., \& Demattê, J. A. M. (1993). Comparações entre as propriedades químicas de solos das regiões da floresta amazônica e do cerrado do Brasil central. Sci. agric., 50(2), 272-286. https://doi.org/10.1590/S0103-90161993000200016. 
715 Dias, L. C., Pimenta, F. M., Santos, A. B., Costa, M. H., Ladle R. J. (2016). Patterns of land 716 use, extensification, and intensification of Brazilian agriculture. Glob. Change 717 Biol., 22 (8), pp. 2887-2903.

718 Dias-Filho, M. B. (2017). Degradação de pastagens: o que é e como evitar. Embrapa, 719 Brasilia, DF, Brazil. ISBN 978-85-7035-688-8.

720 Domeignoz-Horta, L. A., Philippot L., Peyrard C., et al (2018). Peaks of in situ N2O emissions are influenced by $\mathrm{N} 2 \mathrm{O}$ producing and reducing microbial communities across arable soils. Glob. Change Biol., 24: 360-370. https://doi.org/10.1111/gcb.13853

Evans, P. N., Boyd, J. A., Leu, A. O. et al. (2019). An evolving view of methane metabolism in the Archaea. Nat Rev Microbiol 17, 219-232. https://doi.org/10.1038/s41579-018-0136-7

725

726

727

728

729

730

731

732

733

734

735

736

737

738

739

740

741

742

743

744

745

Fearnside, P. M., \& Imbrozio Barbosa, R. (1998). Soil carbon changes from conversion of forest to pasture in Brazilian Amazonia. Forest Ecology and Management, 108(1-2), 147-166. https://doi.org/10.1016/S0378-1127(98)00222-9

Fedarko, M. W., Martino, C., Morton, J. T., González, A., Rahman, G., Marotz, C. A., Minich, J. J., Allen, E. E., \& Knight, R. (2019). Visualizing 'omic feature rankings and log-ratios using Qurro. BioRxiv, 2019.12.17.880047. https://doi.org/10.1101/2019.12.17.880047

Fernandes, S. A. P., Bernoux, M., Cerri, C. C., Feigl, B. J., \& Piccolo, M. C. (2002). Seasonal variation of soil chemical properties and $\mathrm{CO}_{2}$ and $\mathrm{CH}_{4}$ fluxes in unfertilized and Pfertilized pastures in an Ultisol of the Brazilian Amazon. Geoderma, 107(3-4), 227-241. https://doi.org/10.1016/S0016-7061(01)00150-1

Fierer, N., \& Jackson, R. B. (2006). The diversity and biogeography of soil bacterial communities. Proceedings of the National Academy of Sciences of the United States of America, 103(3), 626-631. https://doi.org/10.1073/pnas.0507535103

Figueiredo, E. B., Jayasundara, S., Bordonal, R. O., Berchielli, T. T., Reis, R. A., WagnerRiddle, C., La Scala, N. (2017). Greenhouse gas balance and carbon footprint of beef cattle in three contrasting pasture-management systems in Brazil. Journal of Cleaner Production, 142 (1), 420-431.

Forster, P., V. Ramaswamy, P. Artaxo, T. Berntsen, R. Betts, D.W. Fahey, J. Haywood, J. Lean, D.C. Lowe, G. Myhre, J. Nganga, R. P., \& G. Raga, M. S. and R. V. D. (2007). Changes in Atmospheric Constituents and in Radiative Forcing. In M. T. and H. L. M. Solomon, S., D. Qin, M. Manning, Z. Chen, M. Marquis, K.B. Averyt (Ed.), Climate 
762

763

764

765

766

767

768

769

770

771

772

773

774

775

776

Change 2007: The Physical Science Basis. Contribution of Working Group I to the Fourth Assessment Report of the Intergovernmental Panel on Climate Change. Cambridge University Press. http://www.cgd.ucar.edu/events/20130729/files/Forster-Ramaswamyetal-2007.pdf

Frenzel, P., Rothfuss, F., \& Conrad, R. (1992). Oxygen profiles and methane turnover in a flooded rice microcosm. Biology and Fertility of Soils, 14(2), 84-89. https://doi.org/10.1007/BF00336255

García-Marco, S., Abalos, D., Espejo, R., Vallejo, A., \& Mariscal-Sancho, I. (2016). No tillage and liming reduce greenhouse gas emissions from poorly drained agricultural soils in Mediterranean regions. Science of The Total Environment, 566, 512-520. https://doi.org/ 10.1016/j.scitotenv.2016.05.117

Hanson, R. S., \& Hanson, T. E. (1996). Methanotrophic bacteria. Microbiological Reviews, 60(2), 439-471. http://www.ncbi.nlm.nih.gov/pmc/articles/PMC239451/

Herlemann, D. P., Labrenz, M., Jürgens, K., Bertilsson, S., Waniek, J. J., \& Andersson, A. F. (2011). Transitions in bacterial communities along the $2000 \mathrm{~km}$ salinity gradient of the Baltic Sea. The ISME Journal, 5(10), 1571-1579. https://doi.org/10.1038/ismej.2011.41

Herpin, U., Cerri, C. C., Conceição Santana Carvalho, M., Markert, B., Enzweiler, J., Friese, K., \& Breulmann, G. (2002). Biogeochemical dynamics following land use change from forest to pasture in a humid tropical area (Rondônia, Brazil): a multi-element approach by means of XRF-spectroscopy. Science of The Total Environment, 286(1-3), 97-109. https://doi.org/10.1016/S0048-9697(01)00967-6

Herrero, M., Henderson, B., Havlík, P. et al. (2016). Greenhouse gas mitigation potentials in the livestock Sector. Nature Clim Change 6, 452-461. https://doi.org/10.1038/nclimate2925

Holmes, A. J., Roslev, P., McDonald, I. R., Iversen, N., Henriksen, K., \& Murrell, J. C. (1999). Characterization of Methanotrophic Bacterial Populations in Soils Showing Atmospheric Methane Uptake. Applied and Environmental Microbiology, 65(8), 3312-3318. http://aem.asm.org/content/65/8/3312

Hütsch, B. W., Webster, C. P., \& Powlson, D. S. (1994). Methane oxidation in soil as affected by land use, soil pH and $\mathrm{N}$ fertilization. Soil Biology and Biochemistry, 26(12), 16131622. https://doi.org/10.1016/0038-0717(94)90313-1 
777

778

779

780

781

782

783

784

785

786

787

788

789

790

791

792

793

794

795

796

797

798

799

800

801

802

803

804

805

806

IPCC, I. P. O. C. C. (2007). Contribution of Working Groups I, II and III to the Fourth Assessment Report of the Intergovernmental Panel on Climate Change (L. A. M. B. Metz, O.R. Davidson, P.R. Bosch, R. Dave (ed.)). Cambridge University Press.

Jesus, E. da C., Marsh, T. L., Tiedje, J. M., \& Moreira, F. M. de S. (2009). Changes in land use alter the structure of bacterial communities in Western Amazon soils. The ISME Journal, 3(9), 1004-1011. https://doi.org/10.1038/ismej.2009.47

Kaimowitz, D., Mertens, B., Wunder, S., \& Pacheco, P. (n.d.). Cattle ranching and deforestation in Brazil's Amazon CENTER FOR INTERNATIONAL FORESTRY RESEARCH. Retrieved February 15, 2020, from http://earthtrends.wri.org/text/AGR/variables/193.htm

Kallistova, A. Y., Merkel, A. Y., Tarnovetskii, I. Y., \& Pimenov, N. V. (2017). Methane formation and oxidation by prokaryotes. Microbiology, 86(6), 671-691. https://doi.org/10.1134/S0026261717060091

Keppler, F., Hamilton, J. T. G., Braß, M., \& Röckmann, T. (2006). Methane emissions from terrestrial plants under aerobic conditions. Nature, 439(7073), 187-191. https://doi.org/10.1038/nature04420

Kimura, M. (1980). A simple method for estimating evolutionary rates of base substitutions through comparative studies of nucleotide sequences. Journal of Molecular Evolution, 16(2), 111-120. https://doi.org/10.1007/BF01731581

Knief, C. (2015). Diversity and Habitat Preferences of Cultivated and Uncultivated Aerobic Methanotrophic Bacteria Evaluated Based on pmoA as Molecular Marker. Terrestrial Microbiology, 1346. https://doi.org/10.3389/fmicb.2015.01346

Knief, C., Lipski, A., \& Dunfield, P. F. (2003). Diversity and Activity of Methanotrophic Bacteria in Different Upland Soils. Applied and Environmental Microbiology, 69(11), 6703-6714. https://doi.org/10.1128/AEM.69.11.6703-6714.2003

Kolb, S. (2009). The quest for atmospheric methane oxidizers in forest soils. Environmental Microbiology Reports, 1(5), 336-346. https://doi.org/10.1111/j.1758-2229.2009.00047.x

Kroeger, M.E., Meredith, L.K., Meyer, K.M. et al. Rainforest-to-pasture conversion stimulates soil methanogenesis across the Brazilian Amazon. ISME J (2020). https://doi.org/10.1038/s41396-020-00804-x 
807 Kunhikrishnan, A., Thangarajan, R., Bolan, N.S., Xu, Y., Mandal, S., Gleeson, D.B., Seshadri, R., 2016. Functional Relationships of Soil Acidification, Liming, and Greenhouse Gas Flux, in: Sparks, D. (Ed.), ADVANCES IN AGRONOMY, VOL 139, Advances in Agronomy. ELSEVIER ACADEMIC PRESS INC, 525 B STREET, SUITE 1900, SAN

Lal, R. (2001). Soil degradation by erosion. Land Degradation and Development, 12, 519-539.

Lammel, D. R., Barth, G., Ovaskainen, O., Cruz, L. M., Zanatta, J. A., Ryo, M., de Souza, E.

M., \& Pedrosa, F. O. (2018). Direct and indirect effects of a pH gradient bring insights into the mechanisms driving prokaryotic community structures. Microbiome, 6(1), 106. https://doi.org/10.1186/s40168-018-0482-8

Lau, J.A. \& Lennon, J.T. (2011). Evolutionary ecology of plant-microbe interactions: soil microbial structure alters selection on plant traits. New Phytologist 192, 215-224. https://doi.org/10.1111/j.1469-8137.2011.03790.x

Laurance, W. F., Laurance, S. G., \& Delamonica, P. (1998). Tropical forest fragmentation and greenhouse gas emissions. Forest Ecology and Management, 110(1-3), 173-180. https://doi.org/10.1016/S0378-1127(98)00291-6

Le Mer, J., \& Roger, P. (2001). Production, oxidation, emission and consumption of methane by soils: A review. European Journal of Soil Biology, 37(1), 25-50. https://doi.org/10.1016/S1164-5563(01)01067-6

Liu, C., Holst, J., Brüggemann, N., Butterbach-Bahl, K., Yao, Z., Yue, J., Han, S., Han, X., Krümmelbein, J., Horn, R., \& Zheng, X. (2007). Winter-grazing reduces methane uptake by soils of a typical semi-arid steppe in Inner Mongolia, China. Atmospheric Environment, 41(28), 5948-5958. https://doi.org/10.1016/j.atmosenv.2007.03.017

Margulis, S. (2003). Causes of Deforestation of the Brazilian Amazon. The World Bank. https://doi.org/10.1596/0-8213-5691-7

Martino, C., Morton, J. T., Marotz, C. A., Thompson, L. R., Tripathi, A., Knight, R., \& Zengler, K. (2019). A Novel Sparse Compositional Technique Reveals Microbial Perturbations. MSystems, 4(1). https://doi.org/10.1128/msystems.00016-19 
836

Mendes, L. W., Tsai, S. M., Navarrete, A. A., Hollander, M. de, Veen, J. A. van, \& Kuramae, E. E. (2015). Soil-Borne Microbiome: Linking Diversity to Function. Microbial Ecology, 70(1), 255-265. https://doi.org/10.1007/s00248-014-0559-2

Meyer, K. M., Klein, A. M., Rodrigues, J. L. M., Nüsslein, K., Tringe, S. G., Mirza, B. S., Tiedje, J. M., \& Bohannan, B. J. M. (2017). Conversion of Amazon rainforest to agriculture alters community traits of methane-cycling organisms. Molecular Ecology, 26(6), 1547-1556. https://doi.org/10.1111/mec.14011

Meyer, K.M., Morris, A.H., Webster, K., Klein, A.M., Kroeger, M.E., Meredith, L.K. Brændholt, A., Nakamura, F., Venturini, A., de Souza, L.F., Shek, k. L., Danielson, R., van Haren, J., de Camargo, P.B., Tsai, S.M., Dini-Andreote, F., Mauro, J., Barlow, J., Berenguer, E., Nüsslein, K., Saleska, S., Rodrigues, J.L.M., Bohannan, B.J.M. (2020). Belowground changes to community structure alter methane-cycling dynamics in Amazonia. Environment International, 145, 106131.

Miguez, C. B., Bourque, D., Sealy, J. A., Greer, C. W., \& Groleau, D. (n.d.). Detection and Isolation of Methanotrophic Bacteria Possessing Soluble Methane Monooxygenase (sMMO) Genes Using the Polymerase Chain Reaction (PCR). Microbial Ecology, 33(1), 21-31. https://doi.org/10.1007/s002489900004

Morton, D. C., DeFries, R. S., Shimabukuro, Y. E., Anderson, L. O., Arai, E., Del Bon EspiritoSanto, F., Freitas, R., \& Morisette, J. (2006). Cropland expansion changes deforestation dynamics in the southern Brazilian Amazon. Proceedings of the National Academy of Sciences of the United States of America, 103(39), 14637-14641. https://doi.org/10.1073/pnas.0606377103

Mosier, A. R., Delgado, J. A., \& Keller, M. (1998). Methane and nitrous oxide fluxes in an acid Oxisol in western Puerto Rico: effects of tillage, liming and fertilization. Soil Biology and Biochemistry, 30(14), 2087-2098. https://doi.org/10.1016/S0038-0717(98)00085-6

Navarrete, Acacio A., Tsai, S. M., Mendes, L. W., Faust, K., de Hollander, M., Cassman, N. A., Raes, J., van Veen, J. A., \& Kuramae, E. E. (2015). Soil microbiome responses to the short-term effects of Amazonian deforestation. Molecular Ecology, 24(10), 2433-2448. https://doi.org/10.1111/mec.13172

Nazaries, L., Murrell, J. C., Millard, P., Baggs, L., \& Singh, B. K. (2013). Methane, microbes and models: Fundamental understanding of the soil methane cycle for future predictions. 
In Environmental Microbiology (Vol. 15, Issue 9). https://doi.org/10.1111/14622920.12149

Oliveira, P. P. A., Boaretto, A. E., Trivelin, P. C. O., de Oliveira, W. S., Corsi, M. (2003). Liming and fertilization to restore degraded Brachiaria decumbens pastures grown on an entisol. Sci. Agric., 60 (1), 125-131.

Oksanen, J., Blanchet, F. G., Kindt, R., \& Wagner, L. H. (2015). Vegan: Community ecology package. $\mathrm{R}$ package version 2.2-1. Available online at: http://CRAN.R-project.org/package=vegan

Parada, A. E., Needham, D. M., \& Fuhrman, J. A. (2016). Every base matters: assessing small subunit rRNA primers for marine microbiomes with mock communities, time series and global field samples. Environmental Microbiology, 18(5), 1403-1414. https://doi.org/10.1111/1462-2920.13023

Peres-Neto, P. R., Legendre, P., Dray, S., \& Borcard, D. (2006). Variation partitioning of species data matrices: Estimation and comparison of fractions. Ecology, 87, 2614-2625.

Philippot, L., Hallin, S., Börjesson, G., \& Baggs, E. M. (2009). Biochemical cycling in the rhizosphere having an impact on global change. In Plant and Soil (Vol. 321, Issues 1-2, pp. 61-81). https://doi.org/10.1007/s11104-008-9796-9

Philippot, Laurent, Raaijmakers, J. M., Lemanceau, P., \& van der Putten, W. H. (2013). Going back to the roots: the microbial ecology of the rhizosphere. Nature Reviews Microbiology, 11(11), 789-799. https://doi.org/10.1038/nrmicro3109

Praeg, N., Wagner, A. O., \& Illmer, P. (2017). Plant species, temperature, and bedrock affect net methane flux out of grassland and forest soils. Plant and Soil, 410(1-2), 193-206. https://doi.org/10.1007/s11104-016-2993-z

Pratscher, J., Vollmers, J., Wiegand, S., Dumont, M. G., \& Kaster, A.-K. (2018). Unravelling the Identity, Metabolic Potential and Global Biogeography of the Atmospheric MethaneOxidizing Upland Soil Cluster a. Environmental Microbiology, n/a--n/a. https://doi.org/10.1111/1462-2920.14036

Quast, C., Pruesse, E., Yilmaz, P., Gerken, J., Schweer, T., Yarza, P., Peplies, J., \& Glöckner, F. O. (2012). The SILVA ribosomal RNA gene database project: improved data processing and web-based tools. Nucleic Acids Research, 41(D1), D590-D596. https://doi.org/10.1093/nar/gks1219 
898 Ramakers, C., Ruijter, J. M., Lekanne Deprez, R. H., \& Moorman, A. F. M. (2003).

Reiners, W. A., Bouwman, A. F., Parsons, W. F. J., \& Keller, M. (1994). Tropical Rain Forest

Conversion to Pasture: Changes in Vegetation and Soil Properties. Ecological Applications, 4(2), 363-377. https://doi.org/10.2307/1941940

Rodrigues, J. L. M., Pellizari, V. H., Mueller, R., Baek, K., Jesus, E. da C., Paula, F. S., Mirza, B., Hamaoui, G. S., Tsai, S. M., Feigl, B., Tiedje, J. M., Bohannan, B. J. M., \& Nüsslein, K. (2013). Conversion of the Amazon rainforest to agriculture results in biotic homogenization of soil bacterial communities. Proceedings of the National Academy of Sciences, 110(3), 988-993. https://doi.org/10.1073/pnas.1220608110

Segnini, Aline, Xavier, Alfredo Augusto Pereira, Otaviani-Junior, Pedro Luis, Oliveira, Patrícia Perondi Anchão, Pedroso, André de Faria, Praes, Maria Fernanda Ferreira Menegucci, Rodrigues, Paulo Henrique Mazza, \& Milori, Débora Marcondes Bastos Pereira. (2019). Soil carbon stock and humification in pastures under different levels of intensification in Brazil. Scientia Agricola, 76(1), 33-40. https://doi.org/10.1590/1678-992x-2017-0131

Semrau, J.D., Chistoserdov, A., Lebron, J., Costello, A., Davagnino, J., Kenna, E., Holmes, A.J., Finch, R., Murrell, J.C., Lidstrom, M.E., 1995. Particulate methane monooxygenase genes in methanotrophs. J. Bacteriol. 177, 3071-3079.

Serrano-Silva, N., Sarria-Guzmán, Y., Dendooven, L., \& Luna-Guido, M. (2014). Methanogenesis and Methanotrophy in Soil: A Review. Pedosphere, 24(3), 291-307. https://doi.org/10.1016/S1002-0160(14)60016-3

Steinberg, L. M., \& Regan, J. M. (2008). Phylogenetic Comparison of the Methanogenic Communities from an Acidic, Oligotrophic Fen and an Anaerobic Digester Treating Municipal Wastewater Sludge. Applied and Environmental Microbiology, 74(21), 66636671. https://doi.org/10.1128/AEM.00553-08

Steudler, P. A., Melillo, J. M., Feigl, B. J., Neill, C., Piccolo, M. C., \& Cerri, C. C. (1996). Consequence of forest-to-pasture conversion on $\mathrm{CH}_{4}$ fluxes in the Brazilian Amazon Basin. Journal of Geophysical Research: Atmospheres, 101(D13), 18547-18554. https:// doi.org/10.1029/96JD01551 
928 Tamas, I., Smirnova, A. V., He, Z., \& Dunfield, P. F. (2014). The (d)evolution of 929 methanotrophy in the Beijerinckiaceae-a comparative genomics analysis. ISME Journal, 930 8(2), 369-382. https://doi.org/10.1038/ismej.2013.145

931 Tate, K. R. (2015). Soil methane oxidation and land-use change - from process to mitigation. 932 Soil Biology and Biochemistry, 80, 260-272. https://doi.org/10.1016/j.soilbio.2014.10.010 933 Tian, H., Chen, G., Lu, C., Xu, X., Ren, W., Zhang, B., Banger, K., Tao, B., Pan, S., Liu, M., Zhang, C., Bruhwiler, L., \& Wofsy, S. (2015). Global methane and nitrous oxide emissions from terrestrial ecosystems due to multiple environmental changes. Ecosystem Health and Sustainability, 1(1), 1-20. https://doi.org/10.1890/EHS14-0015.1

van Raij, B., de; Andrade, J.C., Cantarella, H. \& Quaggio, J.A. (2001). Análise química para avaliação da fertilidade de solos tropicais. Campinas, Brazil.

Verchot, L. V., Davidson, E. A., Cattânio, J. H., \& Ackerman, I. L. (2000). Land-Use Change and Biogeochemical Controls of Methane Fluxes in Soils of Eastern Amazonia. Ecosystems, 3(1), 41-56. https://doi.org/10.1007/s100210000009

Wang Y, Yao Z, Zhan Y, Zheng X, Zhou M, Yan G, Wang L, Werner C, Butterbach-Bahl K. Potential benefits of liming to acid soils on climate change mitigation and food security. Global Change Biology. 2021 Mar 20. https://doi.org/10.1111/gcb.15607

Whittenbury, R., Davies, S. L., \& Davey, J. F. (1970). Exospores and Cysts Formed by Methane-utilizing Bacteria. Microbiology, $61(2)$ 219-226. https://doi.org/10.1099/00221287-61-2-219 